Research article Open Access

\title{
Presence and utility of IgA-class antibodies to cyclic citrullinated peptides in early rheumatoid arthritis: the Swedish TIRA project
}

\author{
Anna Svärd ${ }^{1,2}$, Alf Kastbom², Åsa Reckner-Olsson² and Thomas Skogh²
}

\author{
${ }^{1}$ Rheumatology Clinic, Falu Hospital, SE-791 82 Falun, Sweden \\ ${ }^{2}$ AIR/Rheumatology Unit, Department of Clinical and Experimental Medicne, Faculty of Health Sciences, Linköping University Hospital, SE-581 85 \\ Linköping, Sweden
}

Corresponding author: Anna Svärd, anna.svard@ltdalarna.se

Received: 31 Mar 2008 Revisions requested: 13 May 2008 Revisions received: 9 Jun 2008 Accepted: 4 Jul 2008 Published: 4 Jul 2008

Arthritis Research \& Therapy 2008, 10:R75 (doi:10.1186/ar2449)

This article is online at: http://arthritis-research.com/content/10/4/R75

(c) 2008 Svärd et al.; licensee BioMed Central Ltd.

This is an open access article distributed under the terms of the Creative Commons Attribution License (http://creativecommons.org/licenses/by/2.0), which permits unrestricted use, distribution, and reproduction in any medium, provided the original work is properly cited.

\begin{abstract}
Introduction The present study was carried out to assess whether IgA-class antibodies against cyclic citrullinated peptides (IgA anti-CCP) in recent-onset rheumatoid arthritis add diagnostic and/or prognostic information to $\operatorname{lgG}$ anti-CCP analysis.

Methods Serum samples were obtained from 228 patients with recent-onset ( $<12$ months) rheumatoid arthritis at the time of inclusion in the Swedish TIRA cohort (Swedish Early Intervention in Rheumatoid Arthritis). Sera from 72 of these patients were also available at the 3-year follow-up. Disease activity and functional ability measures (erythrocyte sedimentation rate, serum C-reactive protein, 28-joint count Disease Activity Score, physician's assessment of disease activity, and the Swedish version of the Health Assessment Questionnaire) were registered at inclusion and at regular follow-ups during 3 years. An $\lg A$ anti-CCP assay was developed based on the commercially available IgG-specific enzyme immunoassay from EuroDiagnostica (Arnhem, the Netherlands), replacing the detection antibody by an antihuman-lgA antibody. A positive $\lg A$ anti-CCP test was defined by the 99th percentile among healthy blood donors.
\end{abstract}

Results At baseline, a positive lgA anti-CCP test was observed in $29 \%$ of the patient sera, all of which also tested positive for $\lg \mathrm{G}$ anti-CCP at a higher average level than sera containing $\lg G$ anti-CCP alone. The $\lg A$ anti-CCP-positive patients had significantly higher disease activity over time compared with the $\lg \mathrm{A}$ anti-CCP-negative patients. After considering the $\lg \mathrm{G}$ antiCCP level, the disease activity also tended to be higher in the $\lg \mathrm{A}$ anti-CCP-positive cases - although this difference did not reach statistical significance. The proportion of IgA anti-CCPpositive patients was significantly larger among smokers than among nonsmokers.

Conclusion Anti-CCP antibodies of the lgA class were found in about one-third of patients with recent-onset rheumatoid arthritis, all of whom also had IgG anti-CCP. The occurrence of $\lg A$-class antibodies was associated with smoking, and $\lg A$ antiCCP-positive patients had a more severe disease course over 3 years compared with $\lg A$ anti-CCP-negative cases. Although $\lg \mathrm{A}$ anti-CCP analysis does not seem to offer any diagnostic information in addition to $\operatorname{lgG}$ anti-CCP analysis, further efforts are justified to investigate the prognostic implications.

\section{Introduction}

Rheumatoid arthritis (RA) is a chronic disabling inflammatory disease with increased risk of premature death, mainly due to coronary vascular disease [1], but modern therapeutic strategies in early RA have improved the prognosis considerably [24]. Since, however, the clinical manifestations and consequences of RA vary between individuals, as do the responses to therapy, there is an urge to obtain reliable predictors of dis- ease course/outcome and therapy response, in order to allow rational individually tailored therapy regimens. Furthermore, the high direct costs to society for biological agents place further emphasis on the need for reliable predictors.

The discovery of anti-citrullinated peptide/protein antibodies has had a large impact on routine serological testing $[5,6]$. Besides being highly specific diagnostic markers for RA, anti-

$\overline{\mathrm{CCP}}=$ cyclic citrullinated peptides; DMARD = disease-modifying anti-rheumatic drug; HLA = human leukocyte antigen; IgA anti-CCP = IgA-class antibodies against cyclic citrullinated peptides; IgG anti-CCP = IgG-class antibodies against cyclic citrullinated peptides; RA = rheumatoid arthritis; $\mathrm{RF}=$ rheumatoid factor; SE = shared epitope; TIRA = Early Intervention in Rheumatoid Arthritis; TNF = tumour necrosis factor. 
citrullinated peptide/protein antibody tests serve as predictors of disease course and outcome [7-11]. The most widely used and most extensively evaluated anti-citrullinated peptide/protein antibody assay is that developed by van Venrooij and colleagues; that is, IgG-class antibodies to anti-cyclic citrullinated peptides (IgG anti-CCP) [6]. The second-generation antiCCP2 antibody tests have a diagnostic sensitivity for RA equal to that of agglutinating rheumatoid factor (RF) and a disease specificity of $90 \%$ to $99 \%[5,6]$. Like RF, the presence of circulating IgG anti-CCP has been shown to precede clinical onset of disease by several years [9], indicating a pathogenetic role. The combination of HLA-DRB1 genes encoding the shared epitope (SE) and cigarette smoking leads to a markedly increased risk for anti-CCP-positive RA, implying a geneenvironment interaction [12-15].

Compared with RF, anti-CCP is a better prognostic marker of an aggressive disease course with radiological progression $[7,8,10,11]$. Despite the genetic connection, it seems that only anti-CCP - not SE-carriage by itself - is associated with the increased risk of radiological progression [11]. RF is known to occur among all immunoglobulin isotypes. IgA-RF has been stated of particular interest as a predictor of aggressive disease, at least when rabbit lgG is used as the source of antigen for RF detection [16,17]. High circulating levels of RF and immune complexes, in particular $\lg \mathrm{A}-\mathrm{RF}$ and $\lg \mathrm{A}$-containing immune complexes, have also been shown to be associated with systemic rheumatoid vasculitis [18,19], and high levels of IgA-RF have been reported to be associated with poor response to TNF inhibitors [20]. The aim of the present study is to analyse to what extent lgA-class antibodies to anti-cyclic citrullinated peptides ( $\lg A$ anti-CCP) occur in recent-onset RA and how they compare with $\lg \mathrm{G}$ anti-CCP as a predictor of the disease course.

\section{Patients and methods Patients}

Three hundred and twenty patients with recent-onset RA (onset of joint swelling $<12$ months prior to inclusion) were enrolled in the Swedish TIRA project (Swedish Early Intervention in Rheumatoid Arthritis) during 27 months (1996 to 1998) [8]. Of these patients, 97\% fulfilled the 1987 revised American College of Rheumatology classification criteria [21], and the remainder $(n=9)$ met the following criteria: morning stiffness $\geq 60$ minutes, symmetrical arthritis, and arthritis of hands (wrists, metacarpophalangeal or proximal interphalangeal joints) or feet (metatarsophalangeal joints). Serum samples were available from 228 patients at the time of diagnosis, and from 72 of these patients at the 3-year follow-up.

The patients were prescribed disease-modifying anti-rheumatic drugs (DMARDs) as judged appropriate by the treating physicians, who were unaware of both the patients' lgG antiCCP status and IgA anti-CCP status. The prescription of traditional DMARDs (methotrexate, sulfasalazine, anti-malarial drugs, gold, azthioprine) and/or TNF inhibitors was registered at baseline and after $3,6,12,24$, and 36 months. On the same occasions, serum $\mathrm{C}$ reactive protein, the 28-joint count Disease Activity Score [22] and the physician's global assessment of disease activity were registered. Functional disability was also assessed at baseline and after 12, 24 and 36 months using the Swedish version of the Health Assessment Questionnaire [23].

The cigarette smoking status (current smoker (smoker at least until 1 year before inclusion), previous smoker, or never smoker) was registered at inclusion as described previously [24]. The SE was assessed as previously described [25]. DNA was available from 171 of the patients.

\section{Autoantibody analyses}

The second-generation IgG anti-CCP (RA immunoscan mark 2; EuroDiagnostica, Arnhem, the Netherlands) were analysed as described previously [9], and a modification of this diagnostic kit was used to analyse anti-CCP antibodies of the $\lg \mathrm{A}$ class. Patient sera were diluted 1:100 using the diluent provided with the kit. As a secondary antibody we used a horseradish peroxidase-conjugated polyclonal rabbit anti-human $\alpha$ chain antibody (DakoCytomation, Glostrup, Denmark), which was diluted 1:2,000 with the kit diluent. A seven-step serial dilution of a high-levelled $\lg \mathrm{A}$ anti-CCP patient serum served as the calibrator and the results were expressed as arbitrary units $(\mathrm{AU} / \mathrm{ml})$.

Serum samples were analysed in duplicate and the cutoff limit was set at $25 \mathrm{AU} / \mathrm{ml}$ based upon the 99th percentile of 80 blood donors (no differences were seen comparing female and male blood donors). The intra-assay coefficient of variation of the IgA anti-CCP assay was 13\% based upon six sera analysed 13 times each, and the inter-assay coefficient of variation (nine separate analyses) was 15\%.

Particle agglutinating RF tests, which formed the basis for classification as seropositive RA and seronegative RA, respectively, were performed at the diagnostic laboratories affiliated to the local hospitals participating in the study. Isotype-specific RF analyses ( $\lg M$ and $\lg A$ ) were carried out by enzyme immunoassays as described previously [8].

\section{Statistical analysis}

Statistical analyses were performed using SPSS statistical software (version 15.0; SPSS, Chicago, IL, USA). Spearman's rho correlation coefficient was used to detect an association between IgG anti-CCP and IgA-anti-CCP-levels. The MannWhitney $U$ test was used to evaluate the difference in IgG-antiCCP levels between IgA-positive sera and IgA-negative sera, and to assess differences in antibody occurrence/antibody levels between groups with different smoking and SE status. Differences regarding disease activity measures and the Health Assessment Questionnaire at baseline and over time 
were tested by analysis of variance for repeated measurements. Changes in antibody levels over time were analysed by Wilcoxon's signed-rank test.

\section{Ethical considerations}

The participating patients gave their written informed consent, and the study protocol was approved by the regional ethics committee in Linköping, Sweden.

\section{Results}

Patient characteristics in relation to their $\lg \mathrm{A}$ anti-CCP status are presented in Table 1.

\section{IgA anti-CCP versus IgG anti-CCP results}

Sixty-six of the 228 inclusion sera (29\%) tested positive for $\lg \mathrm{A}$ anti-CCP, compared with $64 \%$ regarding $\lg \mathrm{G}$ anti-CCP. All sera testing positive for $\lg A$ anti-CCP were also positive in the $\lg G$ assay, but only $47 \%$ of the sera testing positive for $\lg G$ anti-CCP had anti-CCP antibodies of the IgA class. As illustrated in Figure 1, the levels of IgG anti-CCP and IgA anti-CCP showed a high degree of correlation (Spearman's rho $=0.8, P$ $<0.01)$. The $\lg A$-positive sera had significantly higher levels of $\lg \mathrm{G}$ anti-CCP $(P<0.001)$ as compared with the lgG antiCCP-positive sera without concomitant IgA anti-CCP (Figure 2).

The status of $\lg \mathrm{A}$ anti-CCP positivity remained essentially stable at the 3-year follow-up: 93\% of patients were therefore unchanged regarding $\lg \mathrm{A}$ anti-CCP-positivity; one out of the 72 patients available for comparison between inclusion and the 3-year follow-up (1.4\%) had changed from negative to positive, whereas four out of 72 patients (5.5\%) had changed from positive to negative. The baseline frequency of $\lg A$ antiCCP in these 72 sera did not differ significantly from the remaining 156 patients (31\% and 28\%, respectively). Regarding changes in the antibody level, eight of the $\operatorname{lgA}$ anti-CCPpositive patients showed an increase $>30 \%$ and seven patients showed a decrease $>30 \%$. Overall, however, the median level of $\lg \mathrm{A}$ anti-CCP in the whole patient material increased from $60 \mathrm{AU} / \mathrm{ml}$ to $81 \mathrm{AU} / \mathrm{ml}(P=0.005)$.

\section{IgA anti-CCP status versus disease course}

Analysis of the $\lg \mathrm{A}$ anti-CCP status at baseline in relation to the number of fulfilled American College of Rheumatology classification criteria at inclusion revealed that those patients testing positive had a significantly higher median American College of Rheumatology criterion count (4.73 versus 4.47, $P$ $=0.01$ ). As shown in Figure 3 , the proportion of $\lg A$ anti-CCPpositive cases increased with an increasing count of fulfilled American College of Rheumatology classification criteria.

The erythrocyte sedimentation rate, the 28 -joint count Disease Activity Score, and the Health Assessment Questionnaire scores were consistently higher in patients with $\lg A$ anti-CCP throughout the 3-year follow-up compared with those patients testing negative (Figure 4a); by analysis of variance for repeated measurements, this increase was statistically significant for the erythrocyte sedimentation rate $(P=0.002)$ and the 28-joint count Disease Activity Score $(P=0.0497)$. This trend remained when comparing cases positive for IgG antiCCP alone with IgA anti-CCP-positive cases (Figure $4 \mathrm{~b}$ ), but did not reach statistical significance by analysis of variance.

Table 1

\section{Characteristics of the 228 rheumatoid arthritis patients}

\begin{tabular}{llll} 
& Total & $\begin{array}{l}\text { IgA anti-CCP-positive, IgG anti-CCP- } \\
\text { positive }\end{array}$ & $\begin{array}{l}\text { IgA anti-CCP-negative, lgG anti-CCP- } \\
\text { positive }\end{array}$ \\
\hline Number of patients & 228 & 66 & 72 \\
Mean age (years) & 55 & 57 & 52 \\
Number of women:men & $158: 70$ & $48: 18$ & $46: 26$ \\
$\quad$ Mean age (years) & $54: 59$ & $55: 62$ & $51: 53$ \\
Number of agglutinating rheumatoid factor- & 142 & 56 & 68 \\
positive & 63 & 85 & 84 \\
$\quad$ (\%) & 74 & 98 & 96 \\
IgM-rheumatoid factor-positive (\%) & 114 & 247 & 184 \\
Median level (U/ml) & 73 & 97 & 87 \\
IgA-rheumatoid factor-positive (\%) & 45 & 83 & 58 \\
Median level (U/ml) & 64 & 100 & 100 \\
IgG anti-CCP-positive (\%) & 520 & 1017 & 222 \\
Median level among positive cases (U/ml) & 53
\end{tabular}

$\lg \mathrm{A}$ anti-CCP, IgA-class antibodies against cyclic citrullinated peptides; IgG anti-CCP, IgG-class antibodies against cyclic citrullinated peptides 
Figure 1

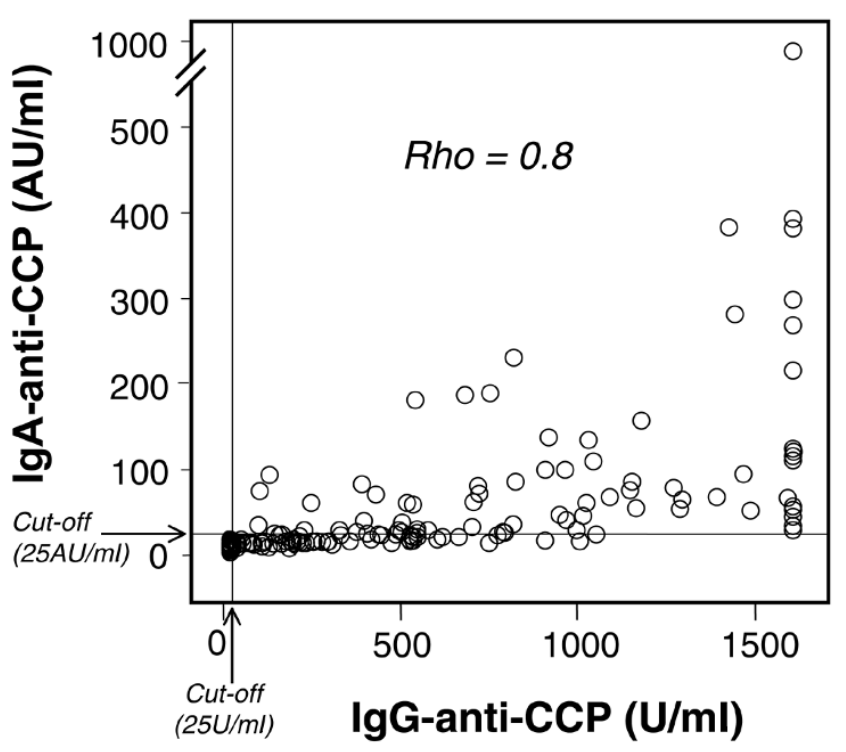

Correlation of IgA-class and IgG-class antibodies against cyclic citrullinated peptides. Correlation between IgG-class antibodies against cyclic citrullinated peptides (IgG anti-CCP) levels and IgA-class antibodies against cyclic citrullinated peptides (IgA anti-CCP) levels in 215 early rheumatoid arthritis sera analysed at inclusion.

Since the IgA-positive patients had higher average levels of IgG anti-CCP (Figure 2), we made an attempt to evaluate the possible influence of a high lgG anti-CCP level regarding disease progression in $\operatorname{lgA}$ anti-CCP-positive patients. Forty patients, $20 \lg A$-positive and $20 \lg A$-negative, with pairwise

Figure 2

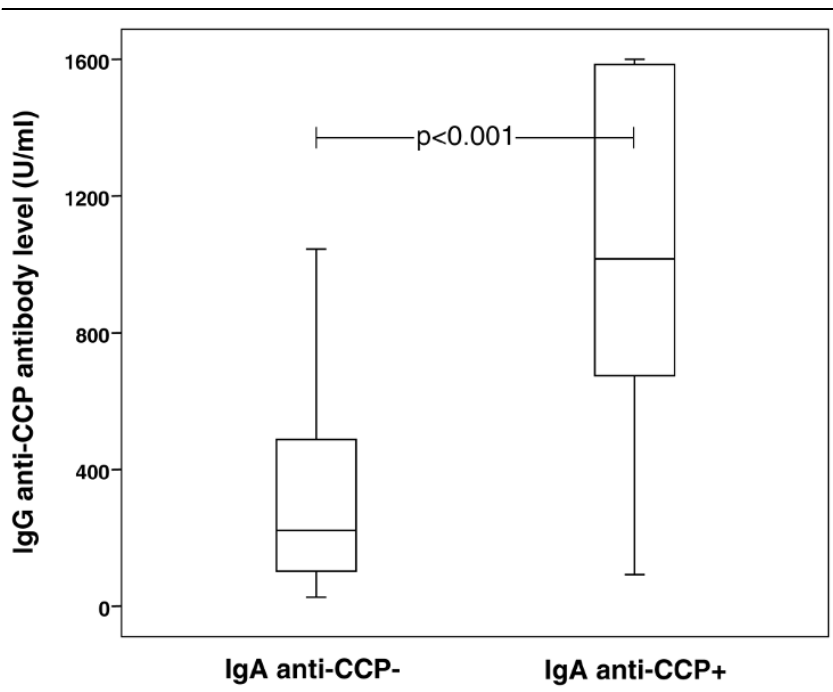

IgG-class antibody levels (median/75-percentiles) in IgG-positive patients with and without IgA-class antibodies against cyclic citrullinated peptides. Box plots illustrating the median IgG-class antibodies against cyclic citrullinated peptides (IgG anti-CCP) levels as well as the 75th percentiles and total ranges among the lgG-positive patients with positive IgA-class antibodies against cyclic citrullinated peptides ( $\lg A$ anti-CCP) tests.
Figure 3

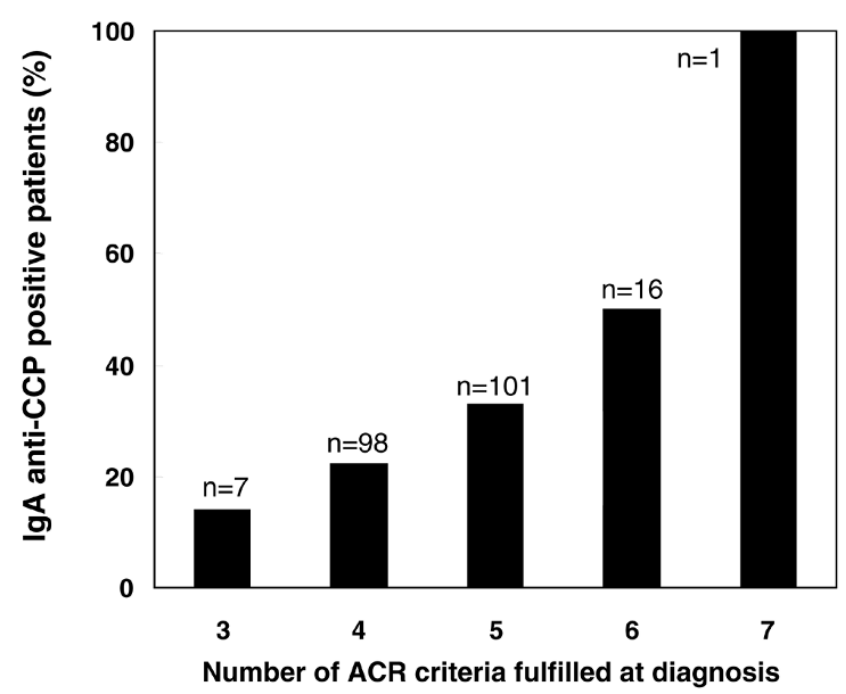

IgA-class antibody status in relation to baseline number of fulfilled American College of Rheumatology criteria. Proportion of IgA-class antibodies against cyclic citrullinated peptides (IgA anti-CCP)-positive patients in relation to the number of American College of Rheumatology (ACR) criteria fulfilled at inclusion.

IgG anti-CCP, 80 to $1,045 \mathrm{U} / \mathrm{ml}$; mean level, $501 \mathrm{U} / \mathrm{ml}$ ). Comparison of these pairwise lgG-matched $\lg A$-positive/lgA-negative cases revealed the same tendency; that is, $\lg A$ anti-CCPpositive patients had a more aggressive disease course over 3 years - although the differences did not reach statistical significance (Figure 4c).

The higher preparedness to prescribe DMARDs to $\lg G$ antiCCP-positive patients as compared with anti-CCP-negative cases in the present cohort [8] was not further enhanced in the IgA anti-CCP-positive cases (Figure 5). We had no access to radiographic follow-up, but at baseline the presence of typical X-ray findings in hands and feet were comparable between anti-CCP-positive and anti-CCP-negative patients (14\% versus $12 \%$ ) for both IgA-class and IgG-class antibodies.

\section{IgA anti-CCP status and IgG anti-CCP status versus smoking and shared epitope}

Forty-three per cent of the current smokers were $\lg \mathrm{A}$ antiCCP-positive ( $n=40$ ), compared with $37 \%$ among previous smokers $(n=38)$ and $25 \%$ among never smokers $(n=150)$. The difference between current smokers and never smokers was significant regarding the proportion of patients testing positive for $\lg \mathrm{A}$ anti-CCP $(P=0.027)$, but not regarding the mean antibody levels of IgA anti-CCP-positive patients. The corresponding difference regarding smoking and $\operatorname{lgG}$ antiCCP status did not reach statistical significance.

When subgrouping the patients based on SE status (double, single, or no SE copies), the presence of IgG anti-CCP 


\section{(a) All patients}

$\lg \mathrm{A}$ anti-CCP +

$\operatorname{IgA}$ anti-CCP -

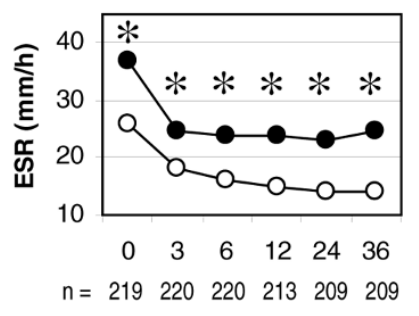

$n=\begin{array}{llllll}219 & 220 & 220 & 213 & 209 & 209\end{array}$

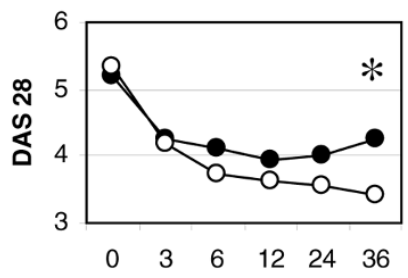

$n=212 \quad 215223209208208$

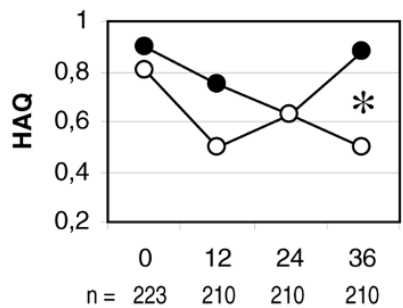

(b) IgG anti-CCP-positive patients

$\lg \mathrm{A}$ anti-CCP +

$\operatorname{IgA}$ anti-CCP -

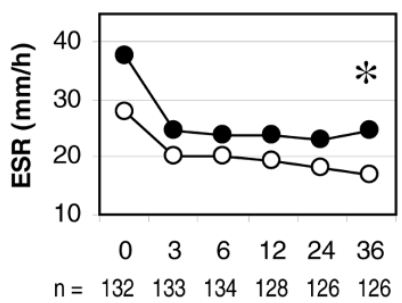

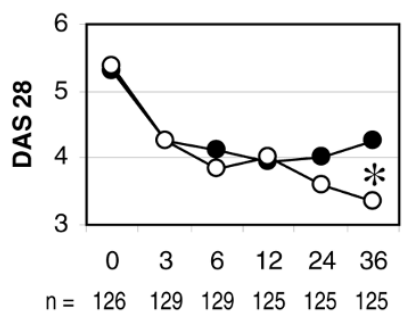

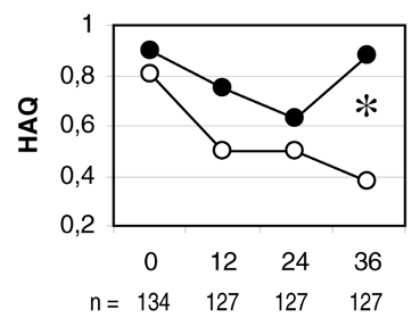

\section{(c) Patients with comparable IgG anti-CCP levels $(n=20+20)$}
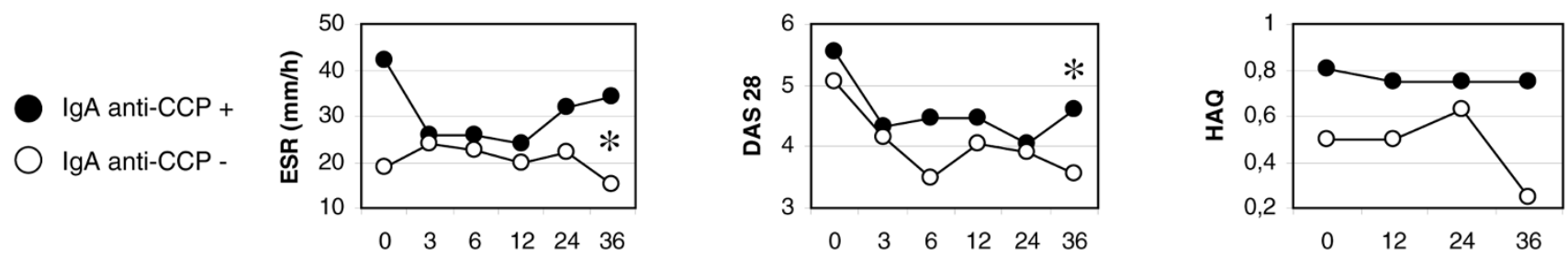

\section{Time after inclusion (months)}

Disease activity and functional ability measures. Course of the erythrocyte sedimentation rate (ESR), the 28-joint count Disease Activity Score (DAS28) and the Health Assessment Questionnaire (HAQ) over 3 years. (a) All patients. (b) IgG-class antibodies against cyclic citrullinated peptides (IgG anti-CCP)-positive RA patients. (c) $20 \mathrm{lgA}$-class antibodies against cyclic citrullinated peptides (IgA anti-CCP)-positive patients and 20 $\lg A$ anti-CCP-negative patients, with pairwise comparable lgG levels. ${ }^{*} P<0.05$.

strongly correlated to SE occurrence in a dose-dependent manner. In the group with two SE copies, 95\% were IgG antiCCP-positive - compared with $70 \%$ in the group with one copy and $33 \%$ in the group without a SE. A much weaker (nonsignificant) trend was recorded regarding $\lg \mathrm{A}$ anti-CCP status versus SE status (39\% in $\mathrm{SE}^{+/+}, 27 \%$ in $\mathrm{SE}^{+/-}$, and $21 \%$ in $\mathrm{SE}^{-/-}$).

\section{Discussion}

Analysis of $\operatorname{lgA}$-class autoantibodies is well established regarding a few disease states, most notably antibodies against endomysium and tissue transglutaminase in coeliac disease [26,27]. Anti-neutrophil cytoplasmic antibodies of the $\lg A$ class have been reported to occur in ulcerative colitis, autoimmune liver diseases, Henoch-Shönlein's purpura, and neutrophilic dermatoses [28-31], and RF of the IgA class has been claimed to be of clinical interest in RA [16-20].

In a study by Verpoort and colleagues in Leiden, IgA anti-CCP antibodies were analysed in early arthritis patients testing positive for IgG anti-CCP [32]. In the present study on early RA we found anti-CCP antibodies of the lgA isotype in 29\% of the patients in total, and in $47 \%$ of the patients testing positive for anti-CCP antibodies of the IgG class. The reason for the slightly lower proportion of $\lg \mathrm{A}$ anti-CCP-positive patients in our study compared with the Leiden group may be the tough cutoff limit applied in the present study. The finding that a positive test in the $\lg A$ assay was restricted to patients with IgG anti-CCP antibodies, however, confirms the findings of Verpoort and colleagues [32]. In a study by Anzilotti and colleagues, antibodies of the IgA class reacting with a citrulli- 
Figure 5

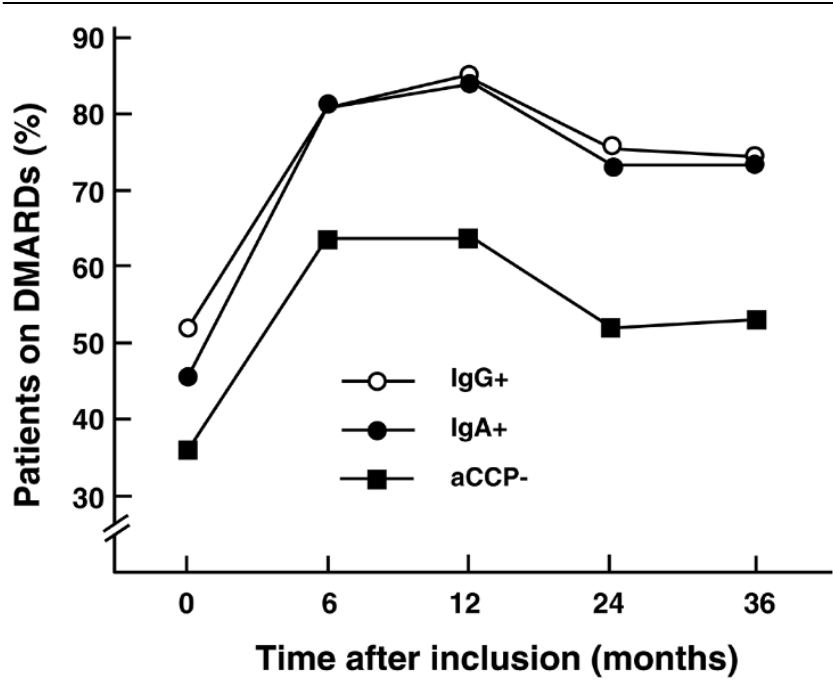

Prescription of disease-modifying anti-rheumatic drugs in patients with different anti-cyclic citrullinated peptide status. Diagram to illustrate the prescription of disease-modifying anti-rheumatic drugs (DMARDs) at different time points after enrolment of patients with different anti-cyclic citrullinated peptide (aCCP) status. Prescribing physicians were unaware of the aCCP results.

nated viral peptide were identified in a few cases of RA who did not have detectable $\lg G$ anti-citrullinated viral peptide antibodies [33].

We and other workers have shown that the presence of $\lg G$ anti-CCP is related to a more severe disease course with poorer outcome compared with patients testing negative for IgG anti-CCP $[7,8,10]$. Similarly, in the present study, patients testing positive for IgA anti-CCP had significantly higher disease activity over 3 years of prospective follow-up compared with those patients testing negative. This may, at least in part, be explained by the concomitant presence of $\lg G$ anti-CCP antibodies. The tendency to higher disease activity in the $\lg A$ anti-CCP-positive/lgG anti-CCP-positive patients as compared with those with $\lg G$ anti-CCP alone could also hypothetically have been related to the higher baseline levels of $\lg G$ anti-CCP, since previous studies indicate that high levels of $\lg$ anti-CCP indicate a more severe disease [34]. We found, however, that IgA-anti-CCP-positive patients tended to have a more severe disease course over 3 years as compared with $\lg A$-negative cases with the same baseline levels of $\lg G$ antiCCP. This observation, suggesting that IgA anti-CCP may possibly have an even better predictive potential than $\lg G$ antiCCP regarding disease course, calls for further prospective studies, including radiographic evaluation, in larger patient materials. Similar to the $\lg G$ anti-CCP status at baseline and 3-year follow-up [8], the presence or absence of IgA anti-CCP at baseline usually remained after 3 years. Contrary to IgGclass antibody levels in serum, however, the average $\lg A$ antiCCP level had not decreased 3 years after diagnosis and instituted DMARD therapy - but rather, on the contrary, had increased. We think this observation is interesting, but it needs further scrutiny in future studies before any far-reaching conclusions can be made.

Klareskog and colleagues have proposed the hypothesis that cigarette smoking acts as a local airway trigger of excessive citrullination leading to immunisation in SE-positive individuals [12]. SE carriage is not, however, an absolute prerequisite to develop immunity to citrullinated antigens. In the present study, $95 \%$ and $70 \%$ of the patients with double SE copies and single SE copies, respectively, were IgG anti-CCP-positive, but as many as $33 \%$ were positive in the group without $\mathrm{SE}$. The corresponding figures regarding IgA anti-CCP antibodies were 39\%, 27\% and 21\%. Despite the low association with SE, the occurrence of IgA-anti CCP significantly correlated to smoking, which again corroborates recent findings by Verpoort and colleagues [35]. We think the IgA response to citrullinated antigens attracts special interest with regard to mucosal triggers, and we propose that $\lg \mathrm{A}$ anti-CCP of mucosal origin should be analysed in future studies.

\section{Conclusion}

IgA anti-CCP analysis does not appear to add a diagnostic benefit to $\lg G$ anti-CCP analysis alone, but the presence of IgA-class antibodies may predict a more severe disease course in early RA. Further studies are justified to shed more light on this question.

\section{Competing interests}

The authors declare that they have no competing interests.

\section{Authors' contributions}

AS, AK and TS participated in the conception and design, acquisition of data, analysis and interpretation of the data, and writing the manuscript. ÅR-O participated in acquisition of the data.

\section{Acknowledgements}

The authors thank Christina Olsson at the Department of Microbiology in Falun for valuable technical advice. They also thank all TIRA coworkers in Eskilstuna, Falun, Jönköping, Kalmar, Linköping, Oskarshamn, Västervik, and Örebro. Jan Ifver is acknowledged for statistical expertise. The study was supported by grants from the Swedish Research Council (Project K2006-74X-14594-043), the Swedish Rheumatism Association, King Gustaf V 80-year foundation, the County Council of Östergötland, the Research Council of South-East Sweden (FORSS), Siv Olsson's and Karin Svensson's Research Foundations, Ester ÅsbergLindberg Memory Foundation, the Olaissonska Foundation, and the

Center for Clinical Research in Dalarna.

\section{References}

1. Michaud K, Wolfe F: Comorbidities in rheumatoid arthritis. Best Pract Res Clin Rheumatol 2007, 21:885-906.

2. Askling J, Dixon W: The safety of anti-tumour necrosis factor therapy in rheumatoid arthritis. Curr Opin Rheumatol 2008, 20:138-144.

3. Cush JJ: Early rheumatoid arthritis -- is there a window of opportunity? J Rheumatol Suppl. 2007, 80():1-7. 
4. Jacobsson LT, Turesson C, Gülfe A, Kapetanovic MC, Petersson IF, Saxne T, Geborek P: Treatment with tumor necrosis factor blockers is associated with a lower incidence of first cardiovascular events in patients with rheumatoid arthritis. J Rheumato/ 2005, 32:1213-1218.

5. Avouac J, Gossec L, Dougados M: Diagnostic and predictive value of anti-cyclic citrullinated protein antibodies in rheumatoid arthritis: a systematic literature review. Ann Rheum Dis 2006, 65:845-851.

6. van Venrooij WJ, Zendman AJ, Pruijn GJ: Autoantibodies to citrullinated antigens in (early) rheumatoid arthritis. Autoimmun Rev 2006, 6:37-41.

7. Forslind K, Ahlmen M, Eberhardt K, Hafström I, Svensson B: Prediction of radiological outcome in early rheumatoid arthritis in clinical practice: role of antibodies to citrullinated peptides (anti-CCP). Ann Rheum Dis 2004, 63:1090-1095.

8. Kastbom A, Strandberg G, Lindroos A, Skogh T: Anti-CCP antibody test predicts the disease course during 3 years in early rheumatoid arthritis (the Swedish TIRA project). Ann Rheum Dis 2004, 63:1085-1089.

9. Rantapää-Dahlqvist S, de Jong BA, Berglin E, Hallmans G, Wadell G, Stenlund H, Sundin U, van Venrooij WJ: Antibodies against cyclic citrullinated peptide and IgA rheumatoid factor predict the development of rheumatoid arthritis. Arthritis Rheum 2003, 48:2741-2749

10. Rönnelid J, Wick MC, Lampa J, Lindblad S, Nordmark B, Klareskog L, van Vollenhoven RF: Longitudinal analysis of citrullinated protein/peptide antibodies (anti-CP) during 5 year follow up in early rheumatoid arthritis: anti-CP status predicts worse disease activity and greater radiological progression. Ann Rheum Dis 2005, 64:1744-1749.

11. van Gaalen FA, Linn-Rasker SP, van Venrooij WJ de Jong BA, Breedveld FC, Verweij CL, Toes RE, Huizinga TW: Autoantibodies to cyclic citrullinated peptides predict progression to rheumatoid arthritis in patients with undifferentiated arthritis: a prospective cohort study. Arthritis Rheum 2004, 50:709-715.

12. Klareskog L, Stolt $P$, Lundberg K, Källberg H, Bengtsson $C$, Grunewald J, Rönnelid J, Harris HE, Ulfgren AK, Rantapää-Dahlqvist S, Eklund A, Padyukov L, Alfredsson L: A new model for an etiology of rheumatoid arthritis: smoking may trigger HLA-DR (shared epitope)-restricted immune reactions to autoantigens modified by citrullination. Arthritis Rheum 2006, 54:38-46.

13. Linn-Rasker SP, Helm-van Mil AH van der, van Gaalen FA, Kloppenburg M, de Vries RR, le Cessie S, Breedveld FC, Toes RE, Huizinga TW: Smoking is a risk factor for anti-CCP antibodies only in rheumatoid arthritis patients who carry HLA-DRB1 shared epitope alleles. Ann Rheum Dis 2006, 65:366-371.

14. Pedersen M, Jacobsen $S$, Garred $P$, Madsen $H O$, Klarlund M, Svejgaard A, Pedersen BV, Wohlfahrt J, Frisch M: Strong combined gene-environment effects in anti-cyclic citrullinated peptidepositive rheumatoid arthritis: a nationwide case-control study in Denmark. Arthritis Rheum 2007, 56:1446-1453.

15. Helm-van Mil AH van der, Verpoort KN, le Cessie S, Huizinga TW, de Vries RR, Toes RE: The HLA-DRB1 shared epitope alleles differ in the interaction with smoking and predisposition to antibodies to cyclic citrullinated peptide. Arthritis Rheum 2007, 56:425-432.

16. Houssien DA, Jonsson T, Davies E, Scott DL: Rheumatoid factor isotypes, disease activity and the outcome of rheumatoid arthritis: comparative effects of different antigens. Scand J Rheumatol 1998, 27:46-53.

17. Lindqvist $E$, Eberhardt $K$, Bendtzen $K$, Heinegård $D$, Saxne $T$ : Prognostic laboratory markers of joint damage in rheumatoid arthritis. Ann Rheum Dis 2005, 64:196-201.

18. Genta MS, Genta RM, Gabay C: Systemic rheumatoid vasculitis: a review. Semin Arthritis Rheum 2006, 36:88-98.

19. Westedt ML, Daha MR, Baldwin WM 3rd, Stijnen T, Cats A: Serum immune complexes containing IgA appear to predict erosive arthritis in a longitudinal study in rheumatoid arthritis. Ann Rheum Dis 1986, 45:809-815.

20. Bobbio-Pallavicini F, Caporali R, Alpini C, Avalle S, Epis OM, Klersy $C$, Montecucco C: High IgA rheumatoid factor levels are associated with poor clinical response to tumour necrosis factor $\alpha$ inhibitors in rheumatoid arthritis. Ann Rheum Dis 2007, 66:302-307.

21. Arnett FC, Edworthy SM, Bloch DA, Mcshane DJ, Fries JF, Cooper NS, Healey LA, Kaplan SR, Liang MH, Luthra HS, Medsger TA Jr,
Mitchell DM, Neustadt DH, Pinals RS, Schaller JG, Sharp JT, Wilder RL, Hunder GG: The American Rheumatism Association 1987 revised criteria for the classification of rheumatoid arthritis. Arthritis Rheum 1988, 31:315-324.

22. Prevoo ML, van 't Hof MA, Kuper HH, van Leeuwen MA, Putte LB van de, van Riel PL: Modified disease activity scores that include twenty-eight-joint counts. Development and validation in a prospective longitudinal study of patients with rheumatoid arthritis. Arthritis Rheum 1995, 38:44-48.

23. Ekdahl $\mathrm{C}$, Eberhardt $\mathrm{K}$, Andersson $\mathrm{SI}$, Svensson B: Assessing disability in patients with rheumatoid arthritis. Use of a Swedish version of the Stanford Health Assessment Questionnaire. Scand J Rheumatol 1988, 17:263-271.

24. Olsson AR, Skogh T, Wingren G: Aetiological factors of importance for the development of rheumatoid arthritis. Scand $J$ Rheumato/ 2004, 33:300-306

25. Kastbom A, Ahmadi A, Söderkvist $P$, Skogh T: The $158 \mathrm{~V}$ polymorphism of Fc gamma receptor type IIIA in early rheumatoid arthritis: increased susceptibility and severity in male patients (the Swedish TIRA project). Rheumatology (Oxford) 2005 44:1294-1298.

26. Grodzinsky E, Hed J, Skogh T: IgA antiendomysium antibodies have a high positive predictive value for celiac disease in asymptomatic patients. Allergy 1994, 49:593-597.

27. Sollid LM, Jabri B: Is celiac disease an autoimmune disorder? Curr Opin Immunol 2005, 17:595-600.

28. Ayoub N, Charuel JL, Diemert MC, Barete S, André M, Fermand JP Piette JC, Francès C: Antineutrophil cytoplasmic antibodies of IgA class in neutrophilic dermatoses with emphasis on erythema elevatum diutinum. Arch Dermato/ 2004, 140:931-936.

29. Ozaltin F, Besbas N, Uckan D, Tuncer M, Topaloglu R, Ozen S Saatci U, Bakkaloglu A: The role of apoptosis in childhood Henoch-Schonlein purpura. Clin Rheumatol 2003, 22:265-267.

30. Peen E, Almer S, Bodemar G, Rydén BO, Sjölin C, Tejle K, Skogh $\mathrm{T}$ : Anti-lactoferrin antibodies and other types of ANCA in ulcerative colitis, primary sclerosing cholangitis, and Crohn's disease. Gut 1993, 34:56-62.

31. Schwarze C, Terjung B, Lilienweiss $P$, Beuers U, Herzog V, Sauerbruch T, Spengler U: IgA class antineutrophil cytoplasmic antibodies in primary sclerosing cholangitis and autoimmune hepatitis. Clin Exp Immunol 2003, 133:283-289.

32. Verpoort KN, Jol-van der Zijde CM, Papendrecht-van der Voort EA loan-Facsinay A, Drijfhout JW, van Tol MJ, Breedveld FC, Huizinga TW, Toes RE: Isotype distribution of anti-cyclic citrullinated peptide antibodies in undifferentiated arthritis and rheumatoid arthritis reflects an ongoing immune response. Arthritis Rheum 2006, 54:3799-3808.

33. Anzilotti C, Riente L, Pratesi F, Chimenti D, Delle Sedie A, Bombardieri S, Migliorini P: IgG, IgA, IgM antibodies to a viral citrullinated peptide in patients affected by rheumatoid arthritis, chronic arthritides and connective tissue disorders. Rheumatology (Oxford) 2007, 46:1579-1582.

34. Berglin E, Johansson T, Sundin U, Jidell E, Wadell G, Hallmans G Rantapää-Dahlqvist $S$ : Radiological outcome in rheumatoid arthritis is predicted by presence of antibodies against cyclic citrullinated peptide before and at disease onset, and by $\operatorname{lgA}$ RF at disease onset. Ann Rheum Dis 2006, 65:453-458.

35. Verpoort KN, Papendrecht-van der Voort EA, Helm-van Mil AH van der, Jol-van der Zijde CM, van Tol MJ, Drijfhout JW, Breedveld FC de Vries RR, Huizinga TW, Toes RE: Association of smoking with the constitution of the anti-cyclic citrullinated peptide response in the absence of HLA-DRB1 shared epitope alleles. Arthritis Rheum 2007, 56:2913-2918. 